\title{
The Influence of Transformational Leadership, Intrinsic Motivation, and Job Satisfaction on Affective Commitments of State Vocational Teachers In West Nias Regency
}

\author{
Jusup Debataraja ${ }^{*}$, Sukarman Purba $^{1}$, Wesly Hutabarat ${ }^{1}$ \\ \{*matakura2ku@gmail.com \} \\ Universitas Negeri Medan, Medan, Indonesia ${ }^{2}$
}

\begin{abstract}
The purpose of this study was to determine the influnce of transformational leadership on teacher job satisfaction, intrinsic motivation on teacher job satisfaction, transformational leadership on teacher affective commitment, intrinsic motivation on teacher affective commitment, and job satisfaction on teacher affective commitment in state vocational schools. West Nias Regency. This research was conducted at State Vocational Schools in West Nias Regency. The study population was 160 teachers and to determine the number of samples used Issac and Michael tables, as many as 110 people with proportional random sampling technique. Data collection was carried out using a questionnaire, after the first trial was conducted. The data analysis technique used consisted of descriptive analysis, requirements analysis test, and path analysis with a significance level of $\alpha$ of 0.05 . The results showed that transformational leadership was directly positive towards job satisfaction, instrinsic motivation had a direct positive effect on job satisfaction, transformational leadership was directly positive towards affective commitment, instrinsic motivation had a direct positive effect on affective commitment and job satisfaction had a direct effect on teacher affective commitments. To reduce the affective commitment the teacher can be done by increasing transformational leadership, instrinsic motivation and teacher's job satisfaction.
\end{abstract}

Keywords: Transformational leadership, instrinsic motivation, job satisfaction, affective commitment.

\section{Introduction}

School as an educational institution or institution as a means to achieve educational goals through the learning process. Schools play a role as a means to implement education which is expected to be able to make the community more advanced. Therefore, the school as the center of education must be able to carry out its functions optimally and its role is to produce a great output of human resources and is expected to contribute to the nation's develop-ment process in the future. In order to achieve these objectives, The Act No. 20 of 2003, concerning National Education Standards, stipulates eight Standards that must be met in implementing education. One standard that is assessed directly related to the quality of graduates indicated by the competence of graduates is the standard of educators and education personnel. Teachers as one of the main factors that determine the quality of education must be professional in carrying out their work in order to create quality education. Professional 
teachers must have good performance. And to produce good performance, a teacher must make commitments and agreements in the work that will be carried out. High commitment makes the teacher more responsible and will try to finish the job well and increase the motivation to teach the teacher. So that teachers are expected to carry out their duties well and produce better quality human resources.

Teachers who have affective commitment can realize the goals of education. so that each teacher must have a high affective commitment. There many factors that influence affective commitment include transformational leadership, intrinsic motivation, and job satisfaction. This study is aimed at analyzing the influence of transformational leadership, intrinsic motivation, and job satisfaction on affective commitments. From the above problems it is said to be worthy of research, namely research entitled the influence of transformational leadership, intrinsic motivation, and teacher job satisfaction on teacher's affective commitment.

\subsection{Affective Commitments}

Affective commitment is related to emotional, identification and involvement of individuals in an organization. Individuals who have this commitment have an emotional attachment to the organization that is reflected through their involvement and feelings of pleasure and enjoy their role in the organization. Individuals will continue to join the organization due to the desire to remain a member of the organization.

According to Schultz \& Schultz affective commitment is also called attitudinal commitment (commitment as attitude), namely the situation when individuals consider the extent to which values and objectives are in accordance with the values and objectives of the organization. Individuals with this type of commitment will identify themselves with the values and goals of the organization, and want to maintain their membership [1].

Teacher's affective commitment is the willingness of the teacher to stay in the organization in this case school which is characterized by emotional attachment to the organization, identification of organizational values and objectives, and involvement in the organization, with indicators: loyalty, pride in the organization he works, participation in organizational development, considers the organization to be the best, and emotionally bound.

\subsection{Transformational Leadership}

In an organization or company, leadership is one important factor, leadership factors can provide a good influence on employees to maximize their work and achieve the desired goals of the company.

Swandari suggests that transformational leadership as a leader has the power to influence subordinates in certain ways. With the application of transformational leadership subordinates will feel trusted, valued, loyal and respectful to their leaders [2].

In the end the subordinates will be motivated to do more than expected. And O'Leary argues that transformational leadership is a leadership style used by a manager if he wants a group to widen its boundaries and have performance beyond the status quo or achieve a series of entirely new organizational goals [3]. Transformational leadership in principle motivates subordinates to do better than what can be done, in other words can increase the trust or confidence of subordinates who will influence the performance improvement.

Transformational leadership is leadership that gives motivation to subordinates to do better than what can be done, in other words can increase the trust or confidence of subordinates who will influence the performance improvement. The principal transformational 
leadership indicator is (1) charismatic, (2) reformer, (3) visionary, (4) inspiration, (5) becoming a model and implementing motivation.

\subsection{Intrinsic Motivation}

Herzberg emphasizes that intrinsic motivation is directly related to the true nature of the work of people who do it in other words related to the content of the work [4]. When a boss does not provide motivational factors for employees not experiencing job satisfaction, with motivational factors employees enjoy job satisfaction and provide high performance. And Luthans asserts that motivation comes from satisfaction with the work itself. Individual intrinsic motivation is to do meaningful or meaningful work that has to do with intrinsic motives, namely persaan, responsibility, achievement, achievement, recognition, etc [5]. Intrinsic motivation is a motivation that encourages a person to excel in the individual, better known as motivational factors. Intrinsic motivation is a driver of work originating from within the worker as an individual in the form of awareness of the importance or benefits or meaning of the work carried out, with indicators: the desire to carry out work optimally, challenges and responsibilities at work, want to achieve, the desire to write good things.

\subsection{Job Satisfaction}

Daryanto said, "In general, the job satisfaction reflects the affective reaction from an individual to both the set of work and work related factors he/she is dealing with" which states that in general job satisfaction reflects the affective reaction of individuals to both collections of work and factors related to the work that he faces [6]. Also said Sagala, who argued that teacher job satisfaction is how the level of pleasure he feels towards the various kinds of work he does. Every person who works expects to get satisfaction from where he works [7]. Basically, job satisfaction is an individual thing because each individual will have different levels of satisfaction according to the values that apply in each individual. The more aspects of the work that are in accordance with the wishes of the individual, the higher the level of satisfaction felt.

Teacher job satisfaction is the statement of the teacher's attitude that is fun and loves his work as a result of the assessment of the experience gained in his work. Job satisfaction indicators are (1) the job itself, (2) salary, (3) promotion, (4) supervision, and (5) co-workers.

\section{Methodology}

The method used in this study is quantitative research using path analysis techniques with the aim of describing four variables namely: affective commitment $(\mathrm{x} 4)$, transformational leadership (x1), intrinsic motivation (x2), and job satisfaction ( $\mathrm{x} 3)$. The population in this study were all State Vocational High School teachers, totalling 160 techers. Sample selection applied to stratified is 110 teachers with simple random sampling. Data collection from this study was obtained by using a questionnaire. The questionnaise used is a Likert model. Each grid made into items with five categories: 5, 4, 3, 2, 1 for possitive statements, and 1, 2, 3, 4, 5 for the otherwise. Data that has been obtained from this study are populations, so that the number of samples obtained described according to each variable. The general description of each variable is displayed in the form of an average score (mean), lowest score, highest score, median (Me), mode (Mo), standard deviation (SD), each variable studied. To examine the relationships between varia-bles individually analyzed by simple correlation techniques. 
While the relationship of independent variables together to the dependent variable used multiple correlation analysis techniques. Besides that the coefficient of determination is also calculated to determine the contribution of each independent variable to The dependent variable before searching for the required prices will first be made a table of frequency distributions and histograms for each research variable.

\section{Result and Discussion}

The study involved 110 respondents from 12 vocational schools. To get an idea of the characteristics of the score distribution of each variable, the following are presented the highest score, lowest score, average price, range, standard deviation, median, and mode of each variable studied. To facilitate the description of each variable, the following is a descriptive statistical summary as shown in table 1 below.

Table 1. Summary of Results of Analysis of Descriptive Statistics

\begin{tabular}{lcccc}
\hline \multicolumn{1}{c}{ Variable } & $\mathrm{X} 1$ & $\mathrm{X} 2$ & $\mathrm{X} 3$ & $\mathrm{X} 4$ \\
\hline N Valid & 110 & 110 & 110 & 110 \\
Mean & 122.09 & 121.69 & 120.69 & 133.49 \\
Median & 121.00 & 118.50 & 120.00 & 131.00 \\
Mode & 120 & 120 & 125 & 130 \\
Standard Deviation & 11.673 & 14.935 & 12.424 & 19.155 \\
Variance & 136.267 & 223.060 & 154.362 & 366.931 \\
Range & 62 & 57 & 54 & 76 \\
Minimum & 98 & 98 & 97 & 100 \\
Maximum & 160 & 155 & 151 & 176 \\
Sum & 13430 & 13386 & 13276 & 14684 \\
Minimum Ideal & 35 & 35 & 37 & 38 \\
Maksimum Ideal & 175 & 175 & 185 & 190 \\
Men Ideal & 105 & 105 & 111 & 114 \\
Standar Deviation Ideal & 23.33 & 23.33 & 24.66 & 25.33 \\
\hline
\end{tabular}

The results of the analysis found that the principal's transformational leadership was included in the good category, teachers' intrinsic motivation included in the category of good, job satisfaction the teacher is included in the good category, and the teacher's affective commitment is also included in the good category, and the teacher's affective commitment is also included in the good category.

Table 2. Summary of Analysis of Research Normality Test Variables

\begin{tabular}{|c|c|c|c|c|c|}
\hline & & $\mathrm{X} 1$ & $\mathrm{X} 2$ & $\mathrm{X} 3$ & $\mathrm{X} 4$ \\
\hline $\mathrm{N}$ & & 110 & 110 & 110 & 110 \\
\hline Normal & Mean & 122.09 & 121.69 & 120.69 & 133.49 \\
\hline \multicolumn{6}{|c|}{ Parameters ${ }^{\mathrm{a}}, \mathrm{b}$} \\
\hline \multicolumn{2}{|c|}{ Std.Deviation } & 11.673 & 14.935 & 12.424 & 19.155 \\
\hline Most & Absolute & .071 & .109 & .071 & .081 \\
\hline Extreme & Positive & .071 & 109 & .071 & .080 \\
\hline Differences & Negative & -.041 & -.060 & -.057 & -.081 \\
\hline Kolmogorov & -Smirnov & .749 & 1.140 & .744 & .845 \\
\hline Z Asymp. Siq & (2-tailed) & .629 & .149 & .637 & .473 \\
\hline
\end{tabular}


Based on the results of calculations in the table above it can be seen that the value of Asymp. Sig (2-tailed) $>0.05$. Thus, it can be concluded that the distribution of all data for each research variable does not deviate from the normal distribution, meaning the assumption of normality has been fulfilled.

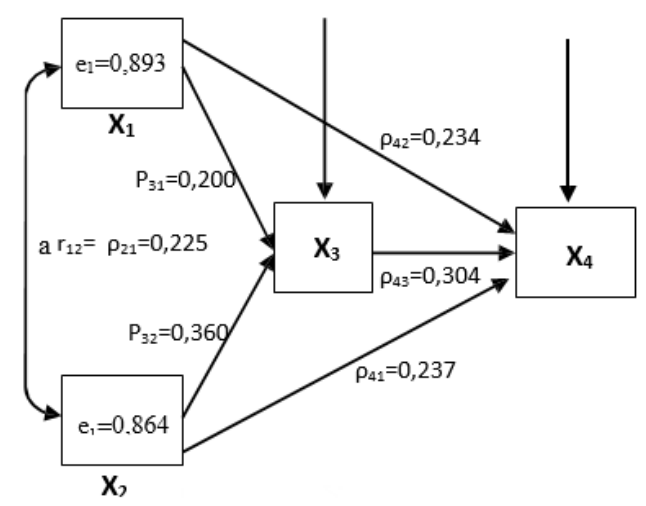

Fig.1. Empirical Causal Relations $\mathrm{X}_{1}, \mathrm{X}_{2}, \mathrm{X}_{3}$, towards $\mathrm{X}_{4}$

Table 3. Summary of Direct and Indirect Effects of Transformational Leadership (X1), Instrinsic Motivation $\left(\mathrm{X}_{2}\right)$ on Job Satisfaction $\left(\mathrm{X}_{3}\right)$

\begin{tabular}{|c|c|c|c|c|}
\hline \multirow[b]{3}{*}{ Variable } & \multicolumn{3}{|c|}{ Influence } & \multirow[b]{3}{*}{$\begin{array}{c}\text { Total } \\
\text { Influnce }\end{array}$} \\
\hline & \multirow[b]{2}{*}{$\begin{array}{l}\text { Directly } \\
\text { to } \mathrm{X}_{3}\end{array}$} & \multicolumn{2}{|c|}{$\begin{array}{l}\text { Not directly from the results of multiplying } \\
\text { the direct path coefficient with the exogenous } \\
\text { variable correlation coefficient }\end{array}$} & \\
\hline & & $\mathrm{X}_{1}$ & $\mathrm{X}_{2}$ & \\
\hline $\mathrm{X}_{1}$ & 0,0400 & - & 0,0162 & 0,0562 \\
\hline $\mathrm{X}_{2}$ & 0,1296 & 0,0162 & - & 0,1458 \\
\hline \multicolumn{4}{|c|}{ Total } & 0,2020 \\
\hline
\end{tabular}

Table 4. Summary of Direct and Indirect Effects of Transformational Leadership (X1), Instrinsic

\begin{tabular}{|c|c|c|c|c|c|}
\hline \multirow{3}{*}{ Variable } & \multicolumn{4}{|c|}{ Infuence } & \multirow{3}{*}{$\begin{array}{c}\text { Total } \\
\text { Influence }\end{array}$} \\
\hline & \multirow{2}{*}{$\begin{array}{l}\text { Directl } \\
\mathrm{y} \text { to } \mathrm{X}_{4}\end{array}$} & \multicolumn{3}{|c|}{$\begin{array}{l}\text { Not directly from the } \\
\text { results of multiplying the direct } \\
\text { path coefficient with the } \\
\text { exogenous variable correlation } \\
\text { coefficient }\end{array}$} & \\
\hline & & $\mathrm{X}_{1}$ & $\mathrm{X}_{2}$ & $\mathrm{X}_{3}$ & \\
\hline $\mathrm{X}_{1}$ & 0,0562 & - & 0,0162 & 0,0156 & 0,0880 \\
\hline $\mathrm{X} 2$ & 0,0924 & 0,0162 & - & 0,0288 & 0,1374 \\
\hline \multirow[t]{2}{*}{$\mathrm{X} 3$} & 0,0548 & 0,0156 & 0,0288 & - & 0,0992 \\
\hline & & Total & & & 0,3246 \\
\hline
\end{tabular}

Based on the results of the path analysis calculation, then it can be stated the direct and indirect effects of the research variables as follows: 
First, proportional direct effect of transformational leadership variable (X1) on job satisfaction (X3) is 0,0040 . This means that $4 \%$ of the variation in job satisfaction scores can be influenced by transformational leadership, while the remaining $96 \%$ is determined by other variables outside of transformational leadership variables.

Second, proportional direct effect of the variable intrinsic motivation (X2) on job satisfaction (X3) is 0,1296 . This means that $12,96 \%$ of the variation in job satisfaction scores can be influenced by intrinsic motivation (X2), while the remaining $87.04 \%$ is determined by other variables outside of intrinsic motivation.

Third, proportional direct effect of transformational leadership variables (X1) on affective commitment (X4) of 0,0562 . This means that $5.62 \%$ of the score variation of teacher's affective commitment can be influenced by transformational leadership, while the remaining $94.38 \%$ is determined by other variables outside of transformational leadership. The proportional effect of the variable intrinsic motivation (X2) on teacher's affective commitment (X4) is 0,0924 . This means that $9,24 \%$ of the variation in the score of affective commitment is influenced by intrinsic motivation, while the remaining $91.76 \%$ is determined by other variables than intrinsic motivation.

Fourth, proportional direct effect of the variable job satisfaction (X3) on teacher's affective commitment $(\mathrm{X} 4)$ is 0,0548 . This means that $5.48 \%$ of the score variation of teacher's affective commitment is influenced by job satisfaction, while the remaining $94.52 \%$ is determined by other variables outside of job satisfaction.

Fifth, proportional indirect influence of transformational leadership variables (X1) on teacher's affective commitment (X4) through job satisfaction (X3) of $1.56 \%$, so that the total direct and indirect effect of Transformational Leadership (X1) on teacher's affective commitment (X4) is 0.0880 and the proportional indirect effect of the variable intrinsic motivation (X2) on teacher's affective commitment (X4) through job satisfaction (X3) is $2,88 \%$, so that the total direct and indirect effect of intrinsic motivation (X2) on teacher's affective commitment (X4) is 0.1374 , and The proportional indirect effect of the variable Job satisfaction $\left(\mathrm{X}_{3}\right)$ on teacher's affective commitment thorugh transformational leadership (X1) is $1,56 \%$, so that the total direct and indirect effect of job satisfaction (X3) on teacher's affective commitment (X4) is 0.0992. Thus, the total direct or indirect influence of Transformational Leadership (X1), Intrinsic Motivation (X2), Job Satisfaction (X3) on Affective Commitment (X4) is 0.3246 . This shows that the total strength of direct or indirect influence is $32.46 \%$ while the remaining $67.54 \%$ is influenced by other factors.

The results of the research that have been stated show that transformational leadership from the results of this study has an influence on teacher job satisfaction in West Nias District Vocational High School. The results of this study prove that teacher job satisfaction is related to the encouragement in the teacher to do the task as a willingness to strive to achieve the objectives of learning. In implementing the leadership of principals in schools, principals need to have the ability to carry out their leadership, including in the implementation of transformational leadership related to the ability to solve every problem faced by teachers in the implementation of learning in school.

The results of the research that have been suggested show that intrinsic motivation from the results of this study has an influence on teacher job satisfaction. The results of this study prove the importance of intrinsic motivation especially in West Nias District Vocational Schools in increasing teacher job satisfaction. Job satisfaction is a person's general attitude towards his job. A person with a high level of satisfaction shows a positive attitude towards his work, while a person who is not satisfied with his job shows a negative attitude towards his work. Motivational relationship to job satisfaction is motivation that is in someone 
is a driving force that embodies a behavior in order to achieve the goal of self satisfaction, it can be added that the relationship of motivation to job satisfaction is when individuals are motivated, they will make positive choices to do something, because satisfy their desires. Motivation is related to satisfaction, where satisfaction can only be increased by high motivation, willingness and ability to perform tasks supported by a comfortable work environment.

The results of the research presented show that there is an influence of transformational leadership on teacher's affective commitment. This proves that the better transformational leadership in it will support the increasing affective commitment of teachers in West Nias District Vocational Schools. Transformational leadership is leadership that motivates employees to perform tasks well, and affective commitment is defined as a type of commitment that is related to an emotional attachment to someone. So that someone who has affective commitment in him then he will continue to work in the organization because they really want (want to) do that.

The results of the research that have been suggested show that there is an influence of intrinsic motivation on teacher's affective commitment. This proves that the better the condition of intrinsic motivation will support the increasing affective commitment of teachers in West Nias District Vocational High School. Intrinsic motivation has an influence on affective commitment, and in this study it is proven that teachers who have high motivation in him will tend to be more enthusiastic in carrying out work, and will lead to a sense of commitment in the teacher to maintain his commitment to the progress of the organization. Teachers who have high motivation will have affective commitment and they have the desire to contribute actively to the organization.

The results of the research that have been suggested show that there is an influence of job satisfaction on teacher's affective commitment. This proves that the better job satisfaction will support the increasing affective commitment of teachers in West Nias District Vocational High Schools. Job satisfaction will always be related to teacher's affective commitment. Affective commitment in this study is perceived as the teacher's attitude as a form of loyalty and teacher involvement in the school at work. Job satisfaction of a teacher in a school, will always be associated in a broader context, namely performance. When teacher performance increases, teacher satisfaction will also increase.

\section{Conclusion}

Based on the data and results of the analysis described above, some conclusions can be drawn as follows:

a. There is a positive direct effect between transformational leadership on teacher job satisfaction. This shows that the improvement of transformational leadership has resulted in an increase in the work satisfaction of teachers of State Vocational Schools in West Nias Regency.

b. There is a positive direct effect between intrinsic motivation on teacher job satisfaction. This shows that an increase in intrinsic motivation results in an increase in job satisfaction for teachers of State Vocational Schools in West Nias Regency.

c. There is a positive direct effect between transformational leadership on teacher's affective commitment. This shows that the improvement of transformational 
leadership has resulted in an increase in affective commitment of teachers of State Vocational Schools in West Nias Regency.

d. There is a positive direct effect between intrinsic motivation on teacher's affective commitment. This shows that an increase in intrinsic motivation results in an increase in affective commitment of teachers of State Vocational Schools in West Nias Regency.

e. There is a positive direct effect between teacher job satisfaction on teacher's affective commitment. This shows that an increase in teacher job satisfaction has resulted in an increase in affective commitment of teachers of State Vocational Schools in West Nias Regency.

\section{References}

[1] D. Schultz and E. . Schultz, Theories of Personality. California: Cole Publishing Company, 2002.

[2] F. Swandari, "Menjadi Perusahaan yang Survive Dengan Transformasional Leadership Manajemen dan Akuntansi," J. Ekon., vol. 1, pp. 93-102, 2003.

[3] E. O'Leary, Kepemimpinan, I. Yogyakarta: Andi, 2001.

[4] Plunket et al., Management: Meeting and Exceding Customer Expectations. USA: Thomson South-Western, 2005.

[5] Luthans F, Prilaku Organisasi. Yokyakarta: ANDI Offset, 2006.

[6] E. Daryanto, "Individual Characteristics, Job Characteristics, and Career Development: A Study on Vocational School Teachers' Satisfaction in Indonesia," Res. J. Educ., vol. 2, no. 8, pp. 698-702, 2014.

[7] S. Sagala, Supervisi Pembelajaran. Bandung: Alfabeta, 2010. 